\title{
Healthy landscapes will help California to mitigate and adapt to climate change
}

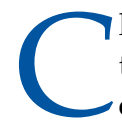

limate change poses a real and pronounced threat to California's landscapes, people and economy. Frequent and wide-ranging wildfires, eroding coastlines, decreasing snowpack and increasing temperatures all affect our lifestyles, health and happiness. Tourists will come to know California as a state on fire with no winter and no water.

Recognizing both the incontrovertible scientific

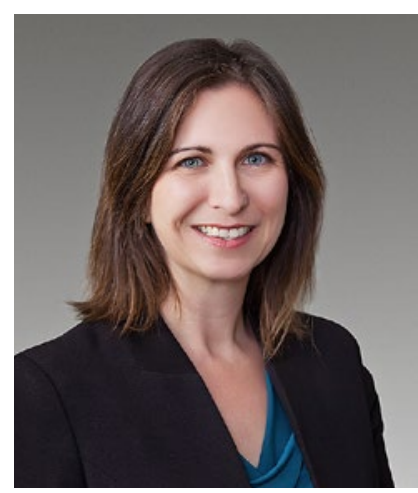

Ashley Conrad-Saydah

Deputy Secretary for Climate Change and Energy Policy, California Environmental Protection Agency evidence that human-caused greenhouse gas emissions affect California and the understanding that human action can make a difference to slow the trend, Gov. Jerry Brown stated in a 2011 speech that "it's time for courage, it's time for creativity and it's time for boldness to tackle climate change." Through executive orders, he set the nation's most ambitious mid-term target for climate mitigation a $40 \%$ reduction in greenhouse gas emission reductions by 2030 - and issued goals to reduce greenhouse gas emissions in our energy, transportation, building and natural resource sectors.

These directives and principles inspire transformation in the way we live, do business, play and move around the state. The goals will prepare us for the future by driving technological innovation, spurring job growth in emerging economic sectors and supporting scientific discovery to rapidly decrease climate-disrupting emissions.

California's landscapes - among them our forests, rangelands, agricultural lands, wetlands, deserts and grasslands - represent one of the best areas for investment to address climate change.

In working to reduce greenhouse gas emissions in all landscapes, we simultaneously receive the benefits of keeping more carbon in those landscapes and safeguarding habitats to survive climate change. These landscapes also provide countless other ecosystem services - erosion control, water quality, water supply, recreation, habitat for fish and wildlife and many more.

To reap the variety of benefits healthy landscapes confer, we must invest in California's lands now. We must set ambitious targets for improving the management of the state's landscapes, and to achieve those targets we must allocate financing that is commensurate with the services these landscapes provide.

Much of California's 30 million-plus acres of forestland is stressed by drought, attacked by pests and recovering from or currently besieged by fire. For decades, our forests have been managed to avoid or suppress fire, rather than to allow a natural fire regime to occur.

Policymakers and scientists are working together to understand the existing and future condition of forests and to develop management actions that will help protect and transition those forests for the future, allowing them to sequester carbon and fight climate change. We are considering a range of activities: pest control and removal of infested trees; thinning to produce sparser forests with a mix of species and ages of trees; prescribed fire; and partnering with communities to develop small-scale wood products and biomass-energy facilities that will engender greater economic security and energy independence in rural California. We know that the policies employed must match the needs of those living in the wildland-urban interface and the specific forest types. We also know that the patchwork of private, tribal and public land management or ownership necessitates dedicated capacity building and engagement.

Designing the management vision is only one part of the solution. Funding the implementation of the vision is a big part of the challenge. Partnerships between public agencies, philanthropic organizations and landowners themselves will allow us all to invest in our critical forests. The state is working to secure funding from the federal Housing and Urban Development agency to implement an innovative community and watershed resilience plan in Tuolumne County. The Sierra Nevada Conservancy and the United States Forest Service are working on a pilot of the Watershed Improvement Program in Tahoe National Forest. And state and federal agencies are developing a Forest Carbon Plan, set for publication in 2016, to detail the implementation process to sequester measurable carbon in our state's forests and help meet Gov. Brown's ambitious climate goals.

Reaching these goals will require a shift in our behavior and in our understanding of forests. Through support of a sustainable and appropriately sized wood products industry, coupled closely with smaller-scale community energy and smart infrastructure growth, we can work towards a healthier, vibrant future for forests and people. By prioritizing the existence and vitality of these lands, we can ensure their health and services for generations of Californians and visitors to come. CA 